Brit. J. industr. Med., 1964, 21, 13.

\title{
BYSSINOSIS IN THE EGYPTIAN COTTON INDUSTRY: CHANGES IN VENTILATORY CAPACITY DURING THE DAY
}

\author{
BY \\ M. A. EL BATAWI, R. S. F. SCHILLING, F. VALIĆ, and JOAN WALFORD \\ From the High Institute of Public Health, Alexandria, The London School of Hygiene and \\ Tropical Medicine, and 'Andrija Stampar' School of Public Health, Zagreb
}

(RECEIVED FOR PUBLICATION AUGUST 2, 1963)

\begin{abstract}
A study in Egypt of 99 male cotton workers in a cotton ginnery and spinning mill, and of a control group of 12 power station workers, showed that the groups exposed to cotton dust had significantly greater falls in indirect maximum breathing capacity (I.M.B.C.) during the shift than groups not exposed to dust. Long-term effects of exposure to cotton dust were studied by examining the I.M.B.C.s measured at the beginning of the shift after adjustment to allow for differences in age and sitting height. The adjusted mean value for those with byssinosis was 10.1 litres/min. lower than for normal cotton workers and 19.6 litres $/ \mathrm{min}$. lower than for the power station workers. Four men were judged by their breathlessness on slight exertion and low ventilatory capacities to be seriously disabled with byssinosis.

In four other mills, all spinning similar types of cotton, changes in I.M.B.C. during the shift correlated highly with dust concentrations and indicated a safe level of dustiness of $1 \mathrm{mg} . / \mathrm{m} .^{3}$ (total dust) at which the effects on ventilatory capacity were minimal.
\end{abstract}

An epidemiological survey by Batawi (1962) provides the first published evidence of the occurrence of byssinosis in the Egyptian cotton industry. Batawi examined more than 600 workers and found that the prevalence of byssinosis was $38 \%$ in the ginneries where the cotton seeds are removed, $53 \%$ in the bale pressing plants, and $27 \%$ in the card rooms of spinning mills. Byssinosis was diagnosed on the characteristic history of tightness in the chest on the first working day of the week, which is Saturday in Arab countries. On this evidence it seemed to be a major problem demanding further investigation.

Exposure to cotton dust has been found to be associated with a fall in ventilatory capacity during the work shift (McKerrow, McDermott, Gilson, and Schilling, 1958). This fall is particularly marked in workers suffering from byssinosis and provides additional and more objective evidence of the hazard of byssinosis to support that based on the characteristic history of chest tightness. It has been used in several recent field and laboratory investigations of persons exposed to vegetable dusts (Bouhuys, Lindell, and Lundin, 1960; Bouhuys, van Duyn, and van Lennep, 1961; Gilson, Stott, Hopwood, Roach, McKerrow, and Schilling, 1962; McKerrow, Roach, Gilson, and Schilling, 1962; McKerrow and Schilling, 1961).

We report a further study of Egyptian workers in a cotton ginnery and spinning mill not included in Batawi's original survey. Tests of ventilatory capacity were used to assess the severity of the effects of cotton dust on respiratory function. Symptoms of byssinosis were recorded and dust concentrations measufed in order to determine their relation with change in ventilatory capacity during the shift, and to get further evidence of the extent of the byssinosis risk in these populations.

In the ginnery, the cotton, which has been picked in the fieids, is opened and mixed by throwing it into the air. This process is called farfara, derived from an Arabic word meaning to flutter (Fig. 1). The cotton is then passed through the gins, which comb out the seeds, after which it is lightly packed into bales to be transported to the nearby spinning mills. In the blow room of the mill it is once again opened and mixed by farfara. It then passes through the first stage of the blowing process where it is fed into 


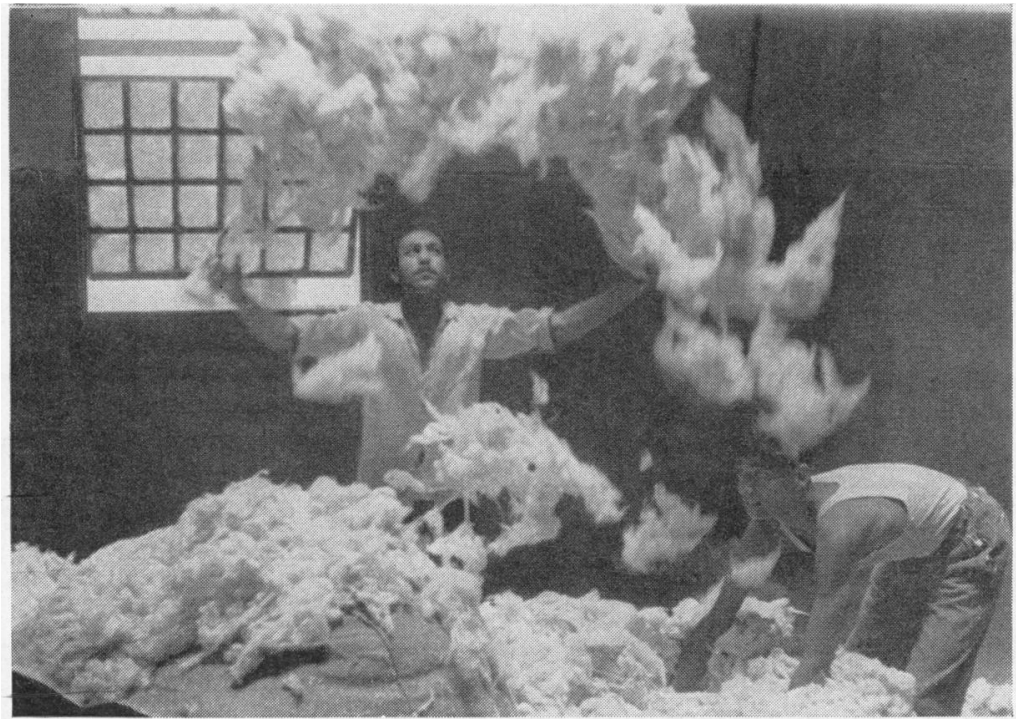

Fig. 1.-The farfara process of mixing cotton by hand.

machines to be teased open and cleaned. At the end of the process it emerges in the form of a lap, which looks like a large roll of cotton wool.

The laps are taken to the card room to be combed out by the carding engines. The strippers clean the teeth of these engines with a power-driven brush without exhaust ventilation and are heavily exposed to dust. Other card room workers do a variety of jobs, such as carrying cotton and cleaning machines.

\section{Methods}

Four main groups were examined: cotton workers in the ginnery, blow room, and card room, and a control group from the power station attached to the spinning mill. For the purpose of analysis the ginnery workers were divided into those 'in dust' and those 'out of dust'. The farfara workers in the blow room were similarly divided into 'inside' and 'outside', while the men employed on the blowing process were divided according to whether they were engaged on the dustiest part of the process at the beginning or on the less dusty stage at the end. This provided a total of seven groups of cotton workers and a control group. Originally, the controls were taken from the bleaching and dyeing section of the spinning mill. They had to be rejected because they failed to co-operate in the ventilatory capacity tests. They were obviously upset because considerable attention had been given to the measurement of dust in other departments whereas no one had visited their work room in which, they said, the air was heavily polluted with steam and was affecting their health.

Those examined were all the men employed on the afternoon shift at the time of the survey, except the farfara group in the blow room who worked only on the one shift from 7 a.m. to 3 p.m.
Ventilatory Capacity.-Ventilatory capacity was estimated from the volume expired in $0.75 \mathrm{sec}$. during a forced expiration using a spirometer with a timer (McKerrow, McDermott, and Gilson, 1960). Care was taken to instruct each worker in the correct method of blowing. After two practice attempts, and discarding faulty blows, the mean of three measurements was used. The results were multiplied by 40 to give the indirect maximum breathing capacity (I.M.B.C.). Before and after each set of tests the spirometer was calibrated and the temperature of the water taken to eliminate the possibility of changes in the timing mechanism, and to allow for ambient temperatures which could bias the readings. The tests were carried out at the beginning and end of the working shift, and the mean change in I.M.B.C. during the period was calculated for each group. It has been found in previous studies that the reduction in I.M.B.C. during a shift is greater on a Monday, the first day back at work after the week-end break, than on a Wednesday or a Thursday (Bouhuys et al., 1961; McKerrow et al., 1958). For the Egyptian workers the maximum effect would be expected on a Saturday, and ideally this is the day on which their ventilatory capacities should have been measured. It was impossible to arrange for all workers to be tested on a Saturday owing to the limited time available, but for two groups, card room and blow room, it was possible to assess the effect of taking readings on other days of the week.

The 35 card room workers were all tested on a Saturday, but 18 of them were also seen on a Monday. The respective mean changes in I.M.B.C. during a shift were -13.1 litres $/ \mathrm{min}$. and $-8.4 \mathrm{litres} / \mathrm{min}$. The difference between the two days was in the expected direction but was not statistically significant. Only the Saturday readings were used for the analysis reported here.

Of the 22 men employed on the blowing process, 12 were tested on a Saturday and 10 on a Sunday. Com- 
parison between the workers on the two days showed no significant difference in mean change; for further analysis the two groups were combined.

All the ginnery workers were tested on a Monday, and any reduction in I.M.B.C. during the shift is likely to be less than they would have experienced on a Saturday.

The men in the farfara section were seen on a Wednesday, but since they had not been exposed to cotton dust on the previous day this was equivalent to testing on a Saturday. The difficulty in comparing this group with other workers arises from their having been the only group tested during the early morning shift. There is clear evidence from a study in Holland (to be published) that the reduction in I.M.B.C. during a morning shift is considerably less than that found during an afternoon shift.

Age, sitting height, and duration of service were recorded for each worker, and questions were asked about respiratory symptoms. Byssinosis was diagnosed on a history of chest tightness and/or breathlessness on a Saturday.

Dust Measurements.- Samples of airborne dust were collected in the areas in which workers were employed to provide a gravimetric measure of the concentration of dust particles of all sizes (total dust). The instrument used was the M.S.A. (110 volts, 60 cycles) electrostatic sampler with an aluminium collecting electrode. Further samples of dust on ledges at head height were taken in the ginnery and in one of the card rooms to be biologically tested for smooth muscle contractor activity.

The time available for the survey limited the number of samples that could be taken. The results give only an indication of the relative dustiness of the various work rooms.

\section{Results}

Acute Effects of Exposure to Cotton Dust.-Since the change in I.M.B.C. during the shift could be affected by the time of day or the day of the week, only internal comparisons between those 'in dust' and 'out of dust' have been made for the ginnery workers and for the men in the farfara section. In both cases the mean fall in I.M.B.C. for the workers exposed to dust is significantly greater than that for the workers not exposed $(P<0.001)$ (Table 1). Significant differences in mean change during the shift were found when power station workers were compared with card room workers $(P<0.001)$ and also when they were compared with the men employed in the blowing process $(P<0.02)$. The difference between card room workers and blow room workers was significant but at a lower level of confidence $(P<0.05)$. In the blowing process itself the mean fall was greater for the men working at the beginning of the process than for those at the end who are less exposed to dust, but the difference was not significant.

A substantial number of the subjects had symptoms of byssinosis, ranging from five out of 23 employed in the blowing process to six out of 12 in the farfara section of the blow room. In previous studies of cotton and flax workers, those with symptoms of byssinosis have shown a greater mean fall in I.M.B.C. during the shift than those without symptoms (McKerrow et al., 1958; Bouhuys et al., 1961). However, since the men with byssinosis have had longer service, this finding could be related to length of exposure and not necessarily to symptoms alone. This suggestion is not supported in this study since the fall in I.M.B.C. of the men with byssinosis is greater than that of the normals for each level of job duration (Table 2).

TABLE 1

PREVALENCE OF BYSSINOSIS AND CHANGES IN I.M.B.C. DURING A SHIFT, IN WORKERS IN A GINNERY AND A COTTON MILL

\begin{tabular}{|c|c|c|c|c|c|c|c|}
\hline \multirow{2}{*}{ Work Place } & \multirow{2}{*}{$\begin{array}{l}\text { No. of } \\
\text { Workers }\end{array}$} & \multirow{2}{*}{$\begin{array}{l}\text { No. with } \\
\text { Byssinosis }\end{array}$} & \multirow{2}{*}{$\underset{\text { (years) }}{\text { Mean }}$} & \multirow{2}{*}{$\underset{\text { (years) }}{\text { Mean Age }}$} & \multirow{2}{*}{$\begin{array}{c}\text { Mean Sitting } \\
\text { Height } \\
\text { (cm.) }\end{array}$} & \multicolumn{2}{|c|}{ Mean I.M.B.C. (litres/min.) } \\
\hline & & & & & & $\begin{array}{c}\text { Initial } \\
\text { Reading }\end{array}$ & $\begin{array}{c}\text { Change } \\
\text { During Shift }\end{array}$ \\
\hline $\begin{array}{l}\text { Ginnery } \\
\text { In dust } \\
\text { Out of dust }\end{array}$ & $\begin{array}{r}15 \\
9\end{array}$ & $\begin{array}{l}5(33 \%) \\
0\end{array}$ & $\begin{array}{l}4 \\
0\end{array}$ & $\begin{array}{l}22 \\
24\end{array}$ & $\begin{array}{l}84 \cdot 5 \\
85.0\end{array}$ & $\begin{array}{l}128 \cdot 7 \\
123 \cdot 5\end{array}$ & $\begin{array}{l}-7.9 \\
-0.9\end{array}$ \\
\hline $\begin{array}{l}\text { Blow room } \\
\text { Farfara (inside) } \\
\text { Farfara (outside) } \\
\text { Beginning of blowing } \\
\text { End of blowing } \\
\text { Total blowing }\end{array}$ & $\begin{array}{l}12 \\
5 \\
12 \\
10 \\
22^{*}\end{array}$ & $\begin{array}{l}6(50 \%) \\
0 \\
3(25 \%) \\
1(10 \%) \\
4(18 \%)\end{array}$ & $\begin{array}{r}13 \\
16 \\
7 \\
8 \\
7\end{array}$ & $\begin{array}{l}46 \\
56 \\
36 \\
37 \\
37\end{array}$ & $\begin{array}{l}85 \cdot 0 \\
82 \cdot 0 \\
81 \cdot 0 \\
82 \cdot 0 \\
81 \cdot 5\end{array}$ & $\begin{array}{r}99 \cdot 5 \\
83 \cdot 7 \\
113 \cdot 4 \\
115 \cdot 4 \\
114 \cdot 3\end{array}$ & $\begin{array}{l}-8.2 \\
+4.7 \\
\pm \quad 9.8 \\
=2.8 \\
-6.6\end{array}$ \\
\hline $\begin{array}{l}\text { Card room } \\
\text { All workers }\end{array}$ & 35 & $15(43 \%)$ & 11 & 38 & $83 \cdot 0$ & $110 \cdot 4$ & $-13 \cdot 0$ \\
\hline $\begin{array}{l}\text { Controls } \\
\text { Power station }\end{array}$ & 12 & $\mathbf{0}$ & $\mathbf{0}$ & 36 & $84 \cdot 0$ & $125 \cdot 4$ & +1.9 \\
\hline
\end{tabular}

* Excluding one byssinotic who worked at both beginning and end of the process.
Ginnery workers in and out of dust
Farfara workers in and out of dust
$\mathbf{P}<0.001$
$\mathbf{P}<\mathbf{0 . 0 0 1}$
All blowers and controls
Card room workers and blowers
Card room workers and controls
Blowers at beginning and at end of process
$\mathbf{P}<0.02$
$P<0.05$
Not significant 
TABLE 2

CHANGE IN I.M.B.C. (LITRES/MIN.) DURING A SHIFT, IN MEN WITH OR WITHOUT BYSSINOSIS WHO HAD BEEN EXPOSED TO DUST

\begin{tabular}{|c|c|c|c|c|c|c|}
\hline \multirow{2}{*}{ Job Duration (years) } & \multicolumn{2}{|c|}{ All Workers } & \multicolumn{2}{|c|}{ With Byssinosis } & \multicolumn{2}{|c|}{ Without Byssinosis } \\
\hline & No. & Mean Change & No. & Mean Change & No. & Mean Change \\
\hline $\begin{array}{r}0- \\
5- \\
10-\end{array}$ & $\begin{array}{l}26 \\
17 \\
41\end{array}$ & $\begin{array}{r}9.2 \\
=6.4 \\
-11.7\end{array}$ & $\begin{array}{r}5 \\
3 \\
23\end{array}$ & $\begin{array}{r}-13.7 \\
-13.2 \\
-15.0\end{array}$ & $\begin{array}{l}21 \\
14 \\
18\end{array}$ & $\begin{array}{l}-8.5 \\
-4.9 \\
-7.4\end{array}$ \\
\hline
\end{tabular}

TABLE 3

RELATION BETWEEN PREVALENCE OF BYSSINOSIS AND FALL IN I.M.B.C. (LITRES/MIN.) DURING A SHIFT IN NORMAL AND BYSSINOTIC WORKERS

\begin{tabular}{|c|c|c|c|c|c|}
\hline \multirow{2}{*}{ Group } & \multirow{2}{*}{$\begin{array}{c}\text { Byssinosis Prevalence } \\
(\%)\end{array}$} & \multicolumn{2}{|c|}{ Byssinotics } & \multicolumn{2}{|c|}{ Normals } \\
\hline & & No. & $\begin{array}{l}\text { Mean Change } \\
\text { (litres/min.) }\end{array}$ & No. & $\begin{array}{c}\text { Mean Change } \\
\text { (litres/min.) }\end{array}$ \\
\hline $\begin{array}{l}\text { Farfara (inside) } \\
\text { Card room } \\
\text { Ginnery (in dust) } \\
\text { Beginning of blowing } \\
\text { End of blowing } \\
\text { Ginnery (out of dust) } \\
\text { Farfara (outside) } \\
\text { Power station }\end{array}$ & $\begin{array}{r}50 \\
43 \\
33 \\
25 \\
10 \\
0 \\
0 \\
0\end{array}$ & $\begin{array}{r}6 \\
15 \\
5 \\
3 \\
1 \\
0 \\
0 \\
0\end{array}$ & $\begin{array}{l}-10 \cdot 2 * \\
-16 \cdot 4 \\
-10 \cdot 1 \\
-22 \cdot 0 \\
-9 \cdot 6 \\
- \\
-\end{array}$ & $\begin{array}{r}6 \\
20 \\
10 \\
9 \\
9 \\
9 \\
5 \\
12\end{array}$ & $\begin{array}{l}-6.3 * \\
-10.4 \\
=6.8 \\
=5.4 \\
=2 \cdot 3 \\
=0.9 \\
+4.7^{*} \\
+1.9\end{array}$ \\
\hline
\end{tabular}

*I.M.B.C. measured on early morning shift and excluded from calculation of correlation coefficient.

Correlation between byssinosis prevalence and fall in I.M.B.C. was as follows:$\begin{array}{ll}\text { Normal workers } & \mathrm{r}=+\mathbf{0 . 9 7 5} \\ \text { Byssinotics } & \mathrm{r}=+0.29\end{array}$

There is also a positive linear relation between the fall in I.M.B.C. and prevalence of byssinosis for workers in different processes $(\mathrm{r}=+0.96)$. This could have arisen merely because the mean change for each group would be weighted by the large reductions in I.M.B.C. of the byssinotics. To examine this further the mean change was calculated separately for byssinotics and normals employed in each process and correlated with prevalence of disease (Table 3; Fig. 2). The correlation remained high for normal cotton workers $(r=+0.975)$ but no

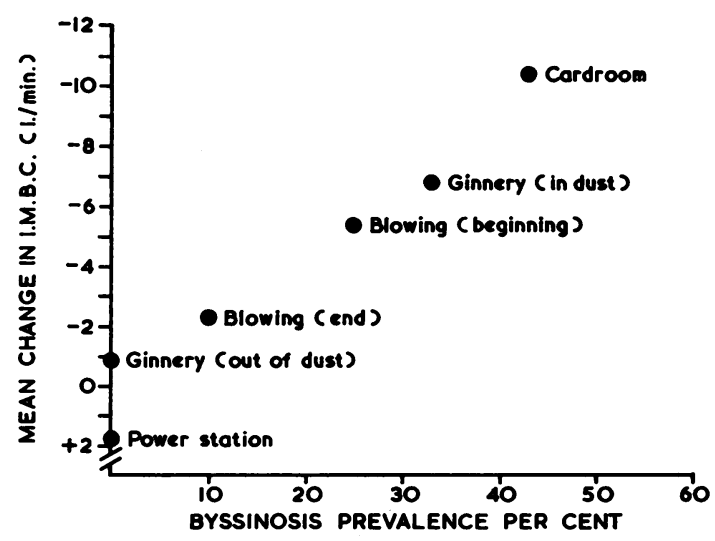

FIG. 2.-Relation between prevalence of byssinosis and fall in I.M.B.C. in cotton workers without byssinosis. significant relation was found for byssinotics $(r=+0 \cdot 29)$.

Long-term Effects of Exposure to Cotton Dust.An indication of the long-term effects of exposure to cotton dust may be obtained from the indirect maximum breathing capacity measured at the beginning of the shift before the reading has been influenced by the acute effects of exposure to dust.

Since the I.M.B.C. decreases with age and increases with sitting height, it is necessary, before making comparisons between groups, to adjust the readings to allow for differences in age and sitting height. To achieve this, an analysis of covariance was carried out on the I.M.B.C.s of the power station workers and of the seven groups of cotton workers. A multiple regression equation was derived with partial regression coefficients of -1.32 litres $/ \mathrm{min}$. per year for the regression of I.M.B.C. on age independent of sitting height $\left(\beta_{1}\right)$ and $+4 \cdot 13$ litres/min. per centimetre for the regression on sitting height independent of age $\left(\beta_{2}\right)$. The $95 \%$ confidence limits were $-1.85 \leqslant \beta_{1} \leqslant-0.79$ and $2.73 \leqslant \beta_{2} \leqslant 5.53$, respectively. However, when the differences between the adjusted means of the eight groups were tested none was statistically significant.

Nevertheless, the results do show some features of interest (Table 4). After adjustment, the mean I.M.B.C. of the power station workers is higher than any of those of the cotton workers. The 
TABLE 4

INITIAL I.M.B.C.S ADJUSTED FOR AGE AND SITTING HEIGHT

\begin{tabular}{l|c|c}
\hline \multicolumn{1}{c|}{ Group } & $\begin{array}{c}\text { No. of } \\
\text { Workers }\end{array}$ & $\begin{array}{c}\text { Mean Adjusted } \\
\text { I.M.B.C. } \\
\text { (1./min.) }\end{array}$ \\
\hline Power station & 12 & $124 \cdot 1$ \\
Blowers (beginning of process) & 12 & 122.7 \\
Blowers (end of process) & 10 & 122.5 \\
Farfara (outside) & 5 & 117.0 \\
Card room & 35 & 114.4 \\
Ginnery (in dust) & 15 & 106.5 \\
Farfara (inside) & 12 & 105.6 \\
Ginnery (out of dust) & 9 & 101.2 \\
\hline
\end{tabular}

similarity in I.M.B.C. shown by the men at the beginning of the blowing process and those at the end supports the negative finding reported previously for these two groups when considering differences in the mean change during the shift. In the farfara section, the adjusted mean I.M.B.C. is higher for the workers outside than for those exposed to dust inside. It is possible that this difference might have been larger but for the fact that there is some interchange of workers between these two groups. In the ginnery, the I.M.B.C. remains higher for the men exposed to dust than for those not exposed, but the men in both groups are young and those working in the dust have only intermittent exposure as ginning is a seasonal operation.

It has been found that not only is the fall in ventilatory capacity during a shift more pronounced for byssinotics than for normal workers, but their initial I.M.B.C.s are also lower (Schilling, 1962). An analysis of covariance was carried out to enable comparisons to be made between the power station workers and the cotton workers divided into men with symptoms of byssinosis and those without symptoms. Since the partial regression coefficients were calculated within different groups from those used in the analysis reported above, they do not have the same values as the previous estimates. The regression of I.M.B.C. on age independent of sitting height was -1.09 litres/min. per year, and the regression on sitting height independent of age
+3.33 litres/min. per centimetre. The overall difference between the adjusted means of the three groups was significant at the 0.05 level of confidence. Individual comparisons showed a significant difference between byssinotics and normal cotton workers $(P<0.05)$, and between byssinotics and power station workers $(P<0.02)$. The difference between normal cotton workers and power station workers was not significant (Table 5).

TABLE 5

INITIAL I.M.B.C.S ADJUSTED FOR AGE AND SITTING HEIGHT, IN NORMAL AND BYSSINOTIC COTTON WORKERS AND POWER STATION WORKERS

\begin{tabular}{|c|c|c|}
\hline Group & $\begin{array}{c}\text { No. of } \\
\text { Workers }\end{array}$ & $\begin{array}{l}\text { Mean Adjusted } \\
\text { I.M.B.C. } \\
\text { (1./min.) }\end{array}$ \\
\hline $\begin{array}{l}\text { Byssinotics (all grades) } \\
\text { Normal cotton workers } \\
\text { Power station workers }\end{array}$ & $\begin{array}{l}31 \\
68 \\
12\end{array}$ & $\begin{array}{l}106 \cdot 7 \\
116 \cdot 8 \\
126 \cdot 3\end{array}$ \\
\hline
\end{tabular}

Byssinotics vs. normal cotton workers: difference $=10 \cdot 1$ litres $/ \mathrm{min}$., $P<0.05$.

Byssinotics vs. power station workers: difference $=19.6 \mathrm{litres} / \mathrm{min}$., $P<0.02$.

Dust Concentrations and Changes in I.M.B.C.Concentrations of dust particles of all sizes (total dust) in the various rooms are given in Table 6. There is a wide range of values, the highest being in the farfara section of the blow room and the lowest in the same room at the end of the blowing process. There is no significant correlation between I.M.B.C. changes during the shift and dust concentrations, even when the farfara section is omitted $(\mathrm{r}=+0 \cdot 16)$. This may be because the bioactivity of the dust varies from room to room and even in the same rooms. Bioactivity, measured by the extent to which cotton dust extracts contract smooth muscle, is present in the plant debris and not in the cotton fibres (Nicholls, 1962). Thus, the fine dust which contains the plant debris is likely to be more biologically active than the coarse dust which contains much cotton fibre.

In the earlier processes, such as ginning where the cotton is thrown into the air, the dust consists

TABLE 6

DUST CONCENTRATIONS AND CHANGES IN I.M.B.C.

\begin{tabular}{|c|c|c|c|c|}
\hline \multirow{2}{*}{ Work Room } & \multirow{2}{*}{ No. of Samples } & \multicolumn{2}{|c|}{ Dust Concentration } & \multirow{2}{*}{$\begin{array}{l}\text { I.M.B.C. Mean } \\
\text { Change (1./min.) }\end{array}$} \\
\hline & & Range (mg./m. ${ }^{3}$ ) & Mean (mg./m..$\left.^{3}\right)$ & \\
\hline $\begin{array}{l}\text { Blow room (farfara) } \\
\text { Ginnery } \\
\text { Blow room (beginning of process) } \\
\text { Card room (during stripping) } \\
\text { Card room (general atmosphere) } \\
\text { Blow room (end of process) }\end{array}$ & $\begin{array}{l}3 \\
\mathbf{4} \\
\mathbf{3} \\
\mathbf{7} \\
\mathbf{7} \\
\mathbf{3}\end{array}$ & $\begin{array}{l}27 \cdot 5-39 \cdot 8 \\
13 \cdot 8-16 \cdot 5 \\
8 \cdot 3-10 \cdot 6 \\
4 \cdot 2-11 \cdot 2^{*} \\
3 \cdot 5-5 \cdot 1^{*} \\
1 \cdot 8-2 \cdot 5\end{array}$ & $\begin{array}{c}34 \cdot 0 \\
15 \cdot 3 \\
9 \cdot 4 \\
9 \cdot 1 \dagger \\
4 \cdot 2 \\
1 \cdot 9\end{array}$ & $\begin{array}{l}-8 \cdot 2 \\
-7 \cdot 9 \\
-\quad 9 \cdot 8 \\
-12 \cdot 8 \\
-14 \cdot 2 \\
-\quad 2 \cdot 8\end{array}$ \\
\hline
\end{tabular}

*Dust samples taken only in two of the three card rooms.

†Calculated mean concentration to which strippers and grinders are exposed. 
TABLE 7

DUST CONCENTRATIONS AND CHANGES IN I.M.B.C. IN CARD ROOMS SPINNING FINE COTTON

\begin{tabular}{|c|c|c|c|c|c|c|}
\hline \multirow{2}{*}{ Room No. } & \multicolumn{3}{|c|}{ Dust Concentration } & \multicolumn{2}{|c|}{ No. of Workers } & \multirow{2}{*}{$\underset{\text { (l./min.) }}{\text { I.M.B.C. }}$} \\
\hline & No. of Samples & Range (mg./m..$^{3}$ ) & Mean (mg./m..$\left.^{3}\right)$ & Total & With Byssinosis & \\
\hline $\begin{array}{l}1 \\
2 \\
3 \\
4\end{array}$ & $\begin{array}{l}6 \\
6 \\
6 \\
6\end{array}$ & $\begin{array}{l}2 \cdot 2-19 \cdot 3 \\
0 \cdot 9-9 \cdot 2 \\
0 \cdot 7-6 \cdot 1 \\
0 \cdot 5-1 \cdot 9\end{array}$ & $\begin{array}{l}6 \cdot 35 \\
4 \cdot 04 \\
3 \cdot 0 \\
1 \cdot 15\end{array}$ & $\begin{array}{r}16 \\
12 \\
9 \\
9\end{array}$ & $\begin{array}{l}4 \\
2 \\
0 \\
0\end{array}$ & $\begin{array}{l}-10.2 \\
-\quad 3.93 \\
-2 \cdot 10 \\
-1.34\end{array}$ \\
\hline
\end{tabular}

Correlation between dust concentration and fall in I.M.B.C.: $r=+0.95$.

mainly of cotton fibres. In the card room during periodic stripping, immense clouds of dust are emitted containing short or broken cotton fibres, whereas the general atmosphere will contain the finer dust which is continuously coming from the carding engines. This may explain why the strippers and other card room workers have similar changes in I.M.B.C., in spite of the strippers being exposed to higher concentrations of dust.

Samples taken from the ginnery and one of the card rooms were assayed on guinea-pig ileum for contractor activity. The card room dust was about twice as potent as that from the ginnery. This may explain why the ginnery workers showed a smaller reduction in I.M.B.C. than the card room workers, although they were exposed to higher dust concentrations. A similar result was found in a study of ginnery and card room workers in Uganda (Gilson et al., 1962).

One of us (M.A. El B.) carried out further tests of ventilatory capacity, at the beginning and end of the shift, on strippers in four card rooms spinning similar types of cotton (Table 7). Here there is a close correlation $(\mathrm{r}=+0.95)$ between change in I.M.B.C. and dust concentration (Fig. 3), both of which are also related to prevalence of byssinosis.

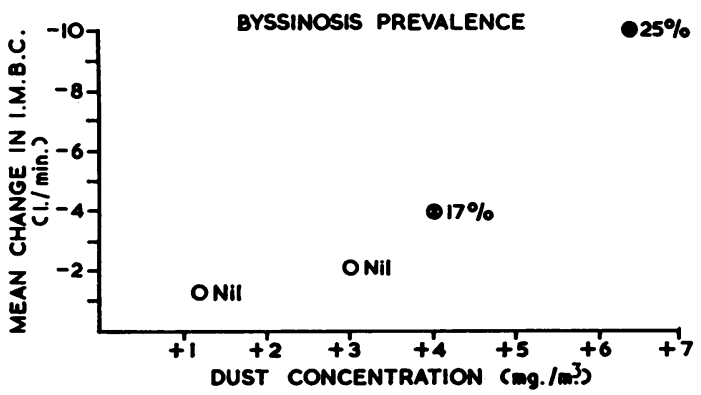

FIG. 3.-Dust concentrations (mg./m. ${ }^{3}$ ) and changes in I.M.B.C. (litres/min.) in card rooms spinning fine cotton.

\section{Discussion}

In this survey prevalences of byssinosis in the ginnery and card room workers were of a similar order to those found in Batawi's original survey, in which a third of the workers at risk had symptoms of byssinosis. The significant difference in the change in I.M.B.C. during the shift of those exposed to dust and those not so exposed confirms the clinical evidence that there is a hazard of byssinosis in the Egyptian cotton industry. There is further evidence that there are serious long-term effects from exposure to cotton dust, causing impaired ventilatory capacity and undue breathlessness on exertion. When adjustments are made for differences in age and sitting height, the mean I.M.B.C. of the byssinotics is $10 \cdot 1$ litres/min. lower than that of normal cotton workers and 19.6 litres/min. lower than that of the power station workers.

Two men from the card room and two from the farfara section of the blow room were judged by their breathlessness on slight exertion and low ventilatory capacities to be seriously disabled with byssinosis. In his first survey, Batawi graded five out of 199 ginnery workers and one out of 149 card room workers as being disabled by byssinosis on account of dyspnoea and reduced vital capacity.

Until recently, disabling byssinosis had been recognized only in the English cotton industry, and this led to the belief that the high atmospheric pollution of the English cotton towns is essential to the production of seriously disabling disease. These surveys in Egypt show that this conception is no longer tenable since many of the towns and villages of the Nile Delta, in which the cotton mills and ginneries are situated, are virtually free from pollution.

In a previous survey, in which prevalence of byssinosis was related to dust concentrations, Roach and Schilling (1960) found that symptoms were virtually absent in card rooms where concentrations were less than $1 \mathrm{mg} . / \mathrm{m}^{3}$. In four card rooms spinning similar types of cotton we have related dust concentrations to change in I.M.B.C. during the shift and prevalence of byssinosis. At this same level of $1 \mathrm{mg} . / \mathrm{m}^{3}$ the effects on ventilatory capacity are minimal. This further evidence supports the suggestion that this figure should be accepted for the time being as a safe level of dust concentration for 
cotton card rooms. For other rooms, such as ginneries and farfara sections where dust contains a higher proportion of inert cotton fibre, safe levels may be substantially higher.

Since in normal workers the change in ventilatory capacity during the shift is closely correlated with the prevalence of byssinosis, it is a useful objective index of risk. It would be even more valuable if it could also be used to detect those who are susceptible to dust and likely to develop byssinosis with permanent disability. However, its value as an indicator of susceptibility can only be determined by a prospective study.

This investigation was made possible by the helpful co-operation of management and employees. We also wish to thank Miss Sheila Farrow for computing assistance and Dr. P. J. Nicholls for testing dust samples for bioactivity.
We have had helpful criticisms in preparing this paper from Dr. J. C. Gilson and his colleagues at the Pneumoconiosis Research Unit, South Wales, and from Dr. S. A. Roach.

\section{REFERENCES}

Batawi, M. A. El (1962). Brit. J. industr. Med., 19, 126

Bouhuys, A., Lindell, S. E., and Lundin, G. (1960). Brit. med. J., $1,324$.

van Duyn, J., and van Lennep, H. J. (1961). Arch. environm. Hlth, $3,499$.

Gilson, J. C., Stott, H., Hopwood, B. E. C., Roach, S. A., McKerrow, C. B., and Schilling, R. S. F. (1962). Brit. J. industr. Med., 19, 9.

McKerrow, C. B., McDermott, M., and Gilson, J. C. (1960). Lancet, $1,149$. Med., 15, 75 .

Roach, S. A., Gilson, J. C., and Schilling, R. S. F. (1962). Ibid., 19,1 .

Nich, and Schilling, R. S. F. (1961). J. Amer. med. Ass., 177, 850.

Nicholls, P. J. (1962). Brit. J. industr. Med., 19, 33.

Roach, S. A., and Schilling, R. S. F. (1960). Ibid., 17, 1.

Schilling, R. S. F. (1962). J. occup. Med., 4, 627. 